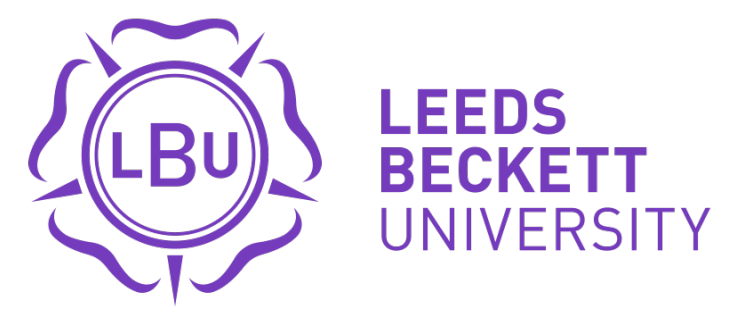

Citation:

Spracklen, K (2017) Sex, Drugs, Satan and Rock and Roll: Re-thinking Dark Leisure, from Theoretical Framework to an Exploration of Pop-rock-metal Music Norms. Annals of Leisure Research, 21

(4). pp. 407-423. ISSN 1174-5398 DOI: https://doi.org/10.1080/11745398.2017.1326156

Link to Leeds Beckett Repository record:

https://eprints.leedsbeckett.ac.uk/id/eprint/3727/

Document Version:

Article (Accepted Version)

This is an Accepted Manuscript of an article published by Taylor \& Francis in Annals of Leisure Research on 10 May 2017, available online: http://www.tandfonline.com/10.1080/11745398.2017.1326156

The aim of the Leeds Beckett Repository is to provide open access to our research, as required by funder policies and permitted by publishers and copyright law.

The Leeds Beckett repository holds a wide range of publications, each of which has been checked for copyright and the relevant embargo period has been applied by the Research Services team.

We operate on a standard take-down policy. If you are the author or publisher of an output and you would like it removed from the repository, please contact us and we will investigate on a case-by-case basis.

Each thesis in the repository has been cleared where necessary by the author for third party copyright. If you would like a thesis to be removed from the repository or believe there is an issue with copyright, please contact us on openaccess@leedsbeckett.ac.uk and we will investigate on a case-by-case basis. 


\section{Sex, drugs, Satan and rock and roll: re-thinking dark leisure, from theoretical framework to an exploration of pop-rock-metal music norms}

\section{Introduction}

Sex and drugs have become impossible to mention without adding in rock and roll. 'Sex and drugs and rock and roll' has become an overused cliché, a reference to the ubiquity of global popular culture and popular music, as well as the belief that popular music is a space where such supposedly dark leisure activities are normalised. Type the phrase into Google and one can see millions of results where it is used exactly as the original version, or is slightly modified; search on Wikipedia and one finds under the disambiguation list various movies, television programmes, songs and albums that use the phrase (https://en.wikipedia.org/wiki/Sex_and_drugs_and_rock_and_roll, accessed 8 November 2016). The phrase 'sex and drugs and rock and roll' was first coined and popularized in the 1977 punk song of the same name by British musician Ian Dury (Birch 2010; Dury 2003; McKay 2009), which gave it both its poetic cadence and its superficial meaning. That is, it rolls off the tongue, and makes some quintessential correspondence between sex and drugs. With the BBC banning the single from its play-lists because of its lyrical content, the song became hugely popular. Although Dury himself was expressing a careful ambiguity about the meaning of having sex and taking drugs in the punk age of rock and roll, the phrase came to point to the excess of musicians associated with rock and heavy metal (Frith 1998; Walser 1993).

By the early 1980s the phrase was so much a part of popular imaginations about popular music that it could be the subject of famous parodies. At the end of the film Spinal Tap (1984), drummer Mick Shrimpton considers his future (that is, of course, if he survives the infamous drum-seat), especially if the sights and sounds and pleasures of being in the 
band comes to an end. Pondering the question from film-maker Marti DeBerg, he replies: 'As long as there's, you know, sex and drugs, I can do without the rock and roll'. In modern leisure spaces, nothing typifies dark leisure as a normative rule better than this supposed alternative, counter-cultural space of pop-rock-metal music. I use pop-rock-metal music in this paper to capture the idea of popular music in its broadest sense. Popular music has unfortunately been used to refer only to the chart music of the global pop music industry. By using pop-rock-metal music I want to emphasise that rock and metal come from and are part of popular music. When I use the phrase pop-rock-metal music, I also include under that all forms of popular dance music1 that owe their origins to popular music: pop-rock-metal music might be described as rock and roll, although rock and roll has come to mean a specific subgenre (but for Dury, at least, and for Spinal Tap, rock and roll is punk and heavy metal). Sex and drugs and rock and roll fit together like the Devil and rock and roll, so this paper will extend the forms of dark leisure under investigation to include Satanism, a key ideology, practice or performance associated with pop-rock-metal music (Cloonan 1995; Kahn-Harris 2007; Spracklen and Spracklen 2012; Spracklen 2014; Walser 1993; Wright 2000). Indeed, selling one's soul to the Devil for musical success (and the sexual exploits success brings) has become a Faustian myth of its own since the early death of blues musician Robert Johnson (Cowley 1981; Graves 2008; Gurlanick 1982; Schroeder 2004; Wells 1983).

Before I come to a discussion of sex and drugs and Satan and rock and roll, some theoretical work on dark leisure is necessary. In the first half of this paper, I will explore the roots of dark leisure theory through a discussion of Stebbins' $(1996,1997,2001)$ definition of deviant leisure, and an analysis and critique of Rojek's (1999) framework for what he calls abnormal leisure. I will then follow the modifications to dark leisure theory in and from leisure studies and cultural studies and show that the concept remains sadly neglected in both subject fields. Then in the second half of the paper, I will construct a new theory of dark 
leisure for our times, out of a case study of the norms and values associated with the idea of the alternative in pop-rock-metal music. I explore the connections between pop-rock-metal music and leisure activities such as sex, drugs and the 'worship' of Satan by drawing on a range of archetypical exemplars of the performativity of dark leisure. Here I will argue that the dark aspect of dark leisure, what is sometimes called deviant or abnormal leisure, is only deviant or abnormal because of two things: the historical influence and continued hegemony of major Western religions, and their idea of sin-filled bodies and minds at leisure. After the mapping of dark leisure through pop-rock-metal music I set out the challenge for leisure studies if it is ever to fully embrace and understand the dark side.

\section{Theoretical framework: dark leisure}

\section{Dark leisure as deviant leisure}

The literature on deviancy is extensive.2 While earlier psychological models of deviancy attempted to predict and ameliorate the effect of deviancy (Cohen 1965), later sociological accounts of deviancy stress the social construction of the deviant, and the social construction of deviancy (Becker 2008; Blackshaw and Crabbe 2004; Cohen 2000; Hebdige 1979). In this account of deviancy, those with political, social and cultural power use that power to label undesirable behaviour and people as deviant (Cohen 2000). The first attempt to understand dark leisure as deviant leisure in the subject field of leisure studies appears in the work of Curtis (1988), who defines it as 'purple' leisure. But the first and most significant theory of deviant leisure appears in the work of Robert Stebbins (1996, 1997, 2001), as another category of leisure alongside the categories of serious leisure and casual leisure previously defined and explored by Stebbins (1982), and what he later called project-based leisure (Stebbins 2005). Deviant leisure can be casual or serious, with casual deviant leisure being 
the tolerable kind undertaken for pleasure, and serious deviant leisure being more preplanned and intolerable (such as murdering someone). Stebbins believes that (1997, 22):

Most deviant leisure fits the description of tolerable deviance. Although its contravention of certain moral norms of a society is held by most of its members to be mildly threatening in most social situations, this form of deviance nevertheless fails to generate any significant or effective communal attempts to control it.

Stebbins is working here with a traditional, psychological model of what is considered to be deviance. Deviance is un-problematically accepted as unacceptable behaviour, the actions of those considered by priests, law-makers and elites as beyond the pale of 'normal' society. He goes on to list what he considers to be forms of casual deviant leisure (Stebbins 1997, 22):

Tolerable deviance undertaken for pleasure - as casual leisure - encompasses a range of deviant sexual activities including cross-dressing, homosexuality, watching sex (e.g. striptease, pornographic films), and swinging and group sex. Heavy drinking and gambling, but not their more seriously regarded cousins alcoholism and compulsive gambling, are also tolerably deviant and hence forms of casual leisure as are the use of cannabis and the illicit, pleasurable, use of certain prescription drugs.

Deviant leisure, it seems for Stebbins, is just sex and drugs and rock and roll. But what is intolerable, what is tolerable, and what is not deviant at all in leisure according to Stebbins is defined by societal norms and values that frame his worldview. The consequence 
for Stebbins (2001) is that hedonist leisure behaviour brings dangers to health and to society. Williams $(2008,208)$ provides a strong critique of this problem of deviance in leisure studies:

Deviant leisure is typically viewed as behavior that violates criminal and noncriminal moral norms. The history of leisure in North America and Europe is connected with moral reform, and subsequently the parameters of legitimate leisure have been overly valorized. Deviant leisure may be a subset of leisure, which is informed by sociology and social psychology, but its roots are in deviance, and deviance has been medicalized.

This is a theme that will continue to recur throughout this paper: dark leisure is only dark from the viewpoint of the hegemonic centre, which uses its power to transform deviance into moral or medical weakness. Let us look now at the important development of the theory of dark leisure in the work of Rojek.

\section{Dark leisure, Chris Rojek and abnormal leisure}

The most important contribution to dark leisure in leisure theory comes in the work of Chris Rojek (1995, 1999, 2000, 2010). In Rojek (1999) he defines and discusses what he calls abnormal leisure, a synonym for deviant leisure or dark leisure. Rojek argues that there are three specific forms of abnormal leisure: invasive; mephitic; and wild. All these forms can be combined to account for and explain the need for all kinds of abnormal leisure. Rojek believes that abnormal leisure is a product of the crisis of the self in late modernity: a consequence of the rise of alienation, post-industrialization and liquidity (a theme he returns to in Rojek 2010). Each of the three forms are particular responses to this existential condition. As he puts it (Rojek 1999, 29): 
Invasive leisure often involves slowly retreating from a society which is seen as unfulfilling or gradually abandoning a part of the self which is no longer regarded to have the capacity for ordinary social interaction. The individual shrinks away from engaging with others and often cultivates solitary recreational habits. The solitariness of the leisure experience serves to re-emphasize one's sense of tragic difference from the rest of society.

Invasive leisure is the retreat into private pleasures and practices. We might think of the sex addict masturbating alone in their bedroom to on-line porn, but equally we might think of someone who collects stamps, or spends all day baking cakes. Invasive leisure is a practice that has become considered to be evidence for individual madness: obsessive, compulsive - even though the madness is a product of the condition of humanity and epistemology in late modernity (Foucault 1991, 2002, 2005). If invasive leisure is the existential crisis of alienation internalised in a retreat from society, other forms of abnormal leisure externalize their discontent. Mephitic leisure, according to Rojek (1999, 29), involves:

Externalizing feelings of aggression and engaging in incidents and/ or careers of abusive leisure with others. Mephitic leisure occurs when the individual transfers feelings of invalidity onto others; equally it may involve regarding the self as truly authentic and judging the rest of society to be inauthentic and unreal.

For Rojek, then, mephitic leisure is a rational pattern of resisting and rejecting the existential crisis through disruptive interactions with others. We can think here of the individuals who choose to join gangs engaged in criminal activity, as well as those who might 
be in a transgressive sub-culture such as mods, punks, rappers, homeys and rockers.3 For all these individuals, the gang or the sub-cultural space is a site for mephitic pleasure and mephitic leisure: drinking and smoking, taking drugs, vandalism; but also just hanging around in a crowd and glaring at passers-by who represent authority and civilized norms and values (Blackshaw and Crabbe 2004; Cohen 2000; Tucker and Matthews 2001). That leisure activity may or may not be illegal, but it is considered dangerous by the authorities. Mephitic leisure is a long-term and carefully planned response to alienation. It is a rational turn for individuals. But mephitic leisure is related to the third, most transgresssive form of abnormal leisure, wild leisure. Rojek suggests $(1999,31)$ :

Wild leisure patterns tend to be sporadic and opportunity based. They are based around contingent acts of transgression around the notion of limits in everyday life, rather than the formation of coherent leisure identities ... Because the legal and juridical system of Western culture is staunchly Cartesian in favouring the preeminence of the rational mind over the body, excitement and release are typically centred upon forms of conduct which celebrate the body. Wild leisure patterns are typically focused on the discharge of surplus capacities and energies that are repressed under the modern social order.

Wild leisure is an intermittent and truly liminal response to contemporary conditions, although Rojek is drawing on older ideas of the carnivalesque and transgression in the work of Bakhtin (1984). Historically, societies have always experienced mephitic and wild leisure, with individuals and groups profaning laws and morals, and with organised mephitic leisure being transformed into wild leisure by those actors who take it too far. 4 Rojek seems to believe that wild leisure is more likely to occur than mephitic leisure these days, because the 
rules that govern and control mephitic leisure are so harsh in late modernity that individuals feel they have no choice other than to be wild.

Rojek's contribution to understanding dark leisure, by providing some definitional focus through the three forms, is important and useful. But like much of Rojek's writing, there is too much speculation and not enough grounding in the social structures and culture that frame contemporary leisure. How exactly are the three forms constructed in later modernity? How exactly do they intersect with each other? How exactly do they intersect with constraints and power inequalities? And are these forms applicable equally to every human in modernity? These are all conceptual, historical and empirical questions that Rojek does not answer. Also, the change of name to abnormal leisure does not seem to have caught on beyond his work. While abnormal leisure is clearly just another way of saying deviant leisure, dark leisure seems to be able to demand something else other than abnormal to make full sense of it. Dark leisure, as I will show in the second half of the paper, is more than just leisure that is defined by society, or hegemonic elites, or religious authorities, as something that is deviant or abnormal.

\section{Dark leisure in leisure studies and cultural studies}

There is some continued interest in dark leisure in the subject field of leisure studies, but it is, ironically, rather liminal to leisure studies research and theory. In the first three issues of the 2016 volume of the journal Leisure Studies, for example, there is only one paper out of twenty-three papers and research notes that could be said to be about something that may be called dark leisure: a case study of the Beltane Fire Festival that uses the idea of the carnivalesque to track the tensions over control and commodification in the life of the event (Matheson and Tinsley 2016). Matheson and Tinsley (2016) do not, however, use dark leisure in the abstract or in the keywords or the title to describe the form of leisure in their paper- 
that is, they do not think their paper is concerned with dark leisure and actively choose not to align their paper with it. The other twenty-two papers and research notes all tread the familiar ground of morally acceptable leisure activities, things that make people healthier in body and mind, or things that help communities cohere and feel good. This is only a small sample of the published work in leisure studies and leisure theory, of course, but I suggest that the morally grounded nature of the leisure in leisure studies means that it continues to exclude research on topics, spaces, activities and practises that are considered by society to be immoral, dark, deviant or abnormal: a similar search in this journal, for example, finds very little that could be termed dark. This is itself a weakness of vision in leisure studies, because so much leisure is dark, and so much of interest critically is the struggle over the borders of what is defined as good leisure and what is defined as bad leisure.

There are sustained developments of dark leisure in leisure studies. Williams (2008, 2009) has continued to argue for the importance of dark leisure as deviant leisure - though this is a re-framed deviant leisure that makes visible the social construction of deviancy (see the 2006 special issue of Leisure/Loisir and the papers in it that challenge the moral nature of the deviant in deviant leisure: Drozda 2006; Franklin-Reible 2006; Galloway 2006; Gunn and Caissie 2006; Williams and Walker 2006). As Williams $(2008,212)$ suggests:

All sorts of practices that are considered unusual and unconventional (deviant) based on norms defined according to specific times and social spaces will remain. When critically assessed from multiple perspectives, some may warrant designation as pathological, dangerous, criminal, or immoral, while others may not. Deviant leisure exists, but scholars must expand their awareness of its range and complexity. 
Although Williams uses the term deviant leisure, this call is really for more research on dark leisure, and more theorizing about dark leisure. In the work of Karl Spracklen and Beverley Spracklen on goths and goth music, for example, it has been argued that dark leisure is a form of communicative leisure, a way for humans to construct their own lifeworlds against the rising tide of instrumental rationality (Spracklen and Spracklen 2012, 2014). Elsewhere, Spracklen suggested that the dark leisure in communicative leisure (exemplified by music sub-cultures such as goth and black metal) has already been commodified, and turned into instrumental leisure: that the communicative form of dark leisure has suffered a 'heat death' (for 'heat death' see Spracklen 2014; more generally, see Spracklen 2015a, 2015b). Others, such as Holland (2004), have explored how dark leisure practices are used to construct alternative sub-cultural identities, linking dark leisure to disruptive, counter-hegemonic identities and politics (see also Dhoest, Malliet, Haer and Segaert 2015; Misiroglu 2015; Winge 2012; Yuen Thompson 2015).

Dark leisure has been more visible in the critical tourism studies literature, where sex tourism (Oppermann 2009; Simoni 2014) and the disorder of night-time economies is explored (Jayne, Valentine and Holloway 2008). There has been a rise of research and theorizing on what is called dark tourism (Stone and Sharpley 2013). Dark tourism started out as a way of describing the rise of experiences based around places and people associated with death: the tourist experiences of concentration camps and battlefields, volcano and other disaster zones, and the many trails dedicated to infamous killers such as Jack the Ripper in the UK (Warkentin 2010). Research on dark tourism explores the ethics of such tourist experiences, the meaning of the experience for the individual seeking the liminal thrill of death, and the place of such experiences in an era of globalisation and increased mobilities (Urry 2012). While dark tourism is a valuable extension of dark leisure, the danger in the literature is that it becomes too self-referential, limited to sketching ideas about darkness and 
liminality taken from other dark tourism researchers. Dark tourism is dark leisure, and is shaped by the same communicative and instrumental rationalities that shape any form 'light' or dark - of leisure (Spracklen 2009, 2011; Spracklen and Spracklen 2014).

Beyond leisure studies, there is a complete absence of dark leisure. To be more precise, there is no reference found to 'dark leisure' as an organizing theoretical and epistemological concept in cultural studies or cultural sociology, though dark leisure is obviously connected with much of the subject of the work in cultural studies. That is, culture is something in which leisure takes place, and a space for people to be at leisure. As many scholars in cultural studies and cultural sociology are interested in liminality, transgression and the profane in sub-cultural spaces (for example, see: Brill 2008; Partridge 2014; Winge 2012) it appears to me that this work is about what we might call dark leisure. Cultural studies and cultural sociology are in debt to ideas of transgression and performativity in subcultural spaces and scenes from Foucault (1991, 2002, 2005), Butler (2006), Deleuze (2014, 2015), Debord (1977), Bataille (1985) amongst others (for example Brill 2008; see also the discussion of alternative cultures in Spracklen 2013, 2015a). There is, then, strong engagement with theories about morality, hegemony and the construction of good and bad behaviour and practice in cultural studies, all of which re-presents debates in leisure studies about deviant leisure, or abnormal leisure, or communicative dark leisure.

\section{Towards an alternative theory of dark leisure}

From the short review of the literature one thing is clear. We need to define and theorise dark leisure more carefully. I hope the leisure part of the term is clear enough but in case it is not, leisure can be anything individuals do that is not clearly delineated as work or something that has to be done to fulfil some basic need.5 People obviously work in the leisure industry, and the work-leisure boundary is often blurred, but this basic definition helps us to make sense of 
what goes on in popular music. There are many people making music for fun, for leisure. Others make music because it is a job, and others have jobs selling that music. The rest of us listen to music, and talk about it, in our leisure time.

If we know about the leisure part, the dark part of dark leisure remains problematic. What is dark about dark leisure? And why is it dark? If it is because of its transgressive or liminal nature, what about it is transgressive? What is being transgressed? The answer has to be some kind of norms and values that have existed historically, and which continue to shape modernity. But then what are those norms and values that are being challenged? And to challenge implies some kind of agency, some action, against the constraints of those norms and values. So where is the agency and power at work? Habermas $(1984,1987)$ provides a way of understanding what is at stake in this dark leisure practice: leisure could be described, as Spracklen has already described it, as a form of communicative rationality in a leisure space that defends the lifeworld, but which is subject to colonisation (Spracklen 2009, 2011, 2013, 2015a). Dark leisure is just another form of leisure (Spracklen and Spracklen 2012). So there may be communicative dark leisure, which operates to allow people to transgress and find meaning and purpose, while at the same time there must be instrumental forms of dark leisure that exclude, control and constrain. But does this work in practice in the socially real world? These are more difficult questions to answer, more difficult concepts to address. But we can start to do this by thinking about the dark side of popular music, which is the subject of the rest of this paper: sex, drugs, Satan and pop-rock-metal music in modernity.

\section{Case study: sex, drugs and Satanism in pop-rock-metal music}

Sex and sexuality

When Colonel Parker first saw Elvis Presley moving his hips while singing his songs of love and lust, he must have realised he had got lucky. At the dawn of the creation of rock and roll 
and pop music, entrepreneurs such as Parker were looking for the right sort of act that would make them millionaires. Elvis ticked all the boxes for Parker: he was young, white, tall and handsome; he could actually sing; and he could make young women scream by shaking those hips. The heteronormative sexual nature of Elvis' performativity allowed him and his backers and labels to make a fortune from selling his records to female fans. His sexualised moves and his lyrics were transformed by rock front-men such as Led Zeppelin's Robert Plant, who, according to Susan Fast (1999), represents the ultimate example of heteronormative, hypermasculine behaviour in pop-rock-metal music, which nonetheless provides female listeners with the freedom to be sexual. Sex and sexuality is not just something performed by heterosexual male artists for heterosexual female fans in pop-rock-metal music. Elvis and Robert Plant were symbols of sexual excitement and subjects of sexual fantasies for gay men as much as straight women (Darling-Wolf 2004; Fast 1999; Swedenburg 1997). And of course women artists in pop-rock-metal music are equally sexualised and sold as willing sexobjects, equally fantasy figures for the masturbatory activities of straight men and gay women (Ashley 2011; Frith 1998; Hurley 1994; Railton 2001).

From Elvis Presley to Rihanna, pop-rock-metal music has been a conduit for sex and sexuality. Many academic writers on pop music note that the music industry is driven by sex, or rather, by lust and desire (Hurley 1994; Railton 2001). First of all, consumers and fans of 'mainstream' pop music buy it because they have sexual feelings for the musicians, or want to use the sexual power of the music to get lucky in bed (Frith, 1998; Fast, 1999; Hesmondhalgh, 2005). Secondly, the makers of this music - the producers, the musicians, but also the industry executives - want to use sex to sell records (Frith 1998; Fast 1999; Railton 2001). The makers of the music products sold in pop-rock-metal music know how the formula of sex and sexuality works. It is believed that fans do not want to buy music made by people considered unattractive. Artists have to embody certain normative ways of being to 
get recording contracts, to get coverage in the media, to make it. That is, artists have to be attractive according to the norms and values of the society in which their music is bought and sold - so, for most pop-rock-metal music, that means the norms and values of beauty in the globalized society in which the industry thrives. The embodiment of sexual attractiveness is not just something that 'mainstream' pop artists have to do, it is something with which all pop-rock-metal music artists have to come to terms. Metal bands have to ensure they look right for the sub-genre in which they are plying their trade. Sometimes this may be desexualized or a negation of sexuality such as in death metal (though the young men still have to have their long hair), and sometimes metal bands may have female singers or musicians who are sexualised in appearance.

Pop-rock-metal music is also a leisure space in which young people can learn about and explore sex and sexuality. This music not only provides mimetic fantasies for would-be sexual agents: it provides spaces and soundtracks for actual sexual encounters, whether it is the true love found after the handing over of a carefully curated mx-tape, or the casual sex in the liminal space of a festival or nightclub. Pop-rock-metal music continues to shape the sex lives and the sexuality of its listeners, as youth sub-cultures enter middle age and slowly decline in numbers. Pop-rock-metal music normalises sex and makes sex something fun, something pleasurable, something human.

This normalisation and embodiment of sex is, though, complicated by the forms of gender and sexuality at work in the construction and reception of pop-rock-music music (Fast 1999; Spracklen 2015b). Is the sex and sexuality work liberating, or constraining, the leisure lives of the listeners/watchers? In the film Spinal Tap, the band is constantly surrounded by un-speaking groupies, young women who are with the musicians as sex objects. The band's album covers are routinely sexualized and sexually offensive to women. When at last the band's powers are fading as a chart act, the label finally has power of its own to ban the cover 
for the new album because it is 'sexist' (even though the band themselves think the cover is 'sexy'). In some genres and scenes, then, such as rock and rap music, sex can become the embodiment of hegemonic masculinity (Spracklen 2015b). This can be mimetic, or actual, sex - and either way, such sex is a product of unequal power relationships that turn women into male sex objects with no power to say no.

At this point in any discussion of sex and sexuality in pop-rock-music, a feminist critique of the hegemonic power of heteronormativity comes close to traditional, Jewish, Christian and Islamic moralities about sex and sexuality. There is a huge difference between feminism and Abrahamic theology, however. In these major world religions there are clear rules about what is allowed, and what is forbidden, in terms of sex and sexuality (Lindsey 2015; Milton-Edwards 2013). Men have power over women, even over the choice of having sex. In this Abrahamic morality, sex is something that should only happen in marriage between a man and his wife. Homosexuality is wrong, and sex outside of the sacred bonds of marriage is wrong. In the sacred laws and commands associated with these three religions and especially in their modern, fundamentalist variants - there is an uncompromising fear of sex and sexuality as leisure activities that are sinful, or evil (Patton 1985; Runkel 1998). Poprock-metal music encourages young people to feel free about sexuality. People use pop-rockmetal music - dance music especially - to socialise and to find sexual partners. So this leads to a reaction against pop-rock-metal music as evil, the work of the evil forces of the Devil, because it is linked to sex and sexual freedom. In the Christian West, this action against poprock-music has taken the form of campaigns by conservative Christian groups against rock and roll from the 1950s through to today (Frith 1998; Howard and Streck 1996; Wright 2000). In the Islamic world, hard-line Sunni and Shia theologians make similar arguments to their Christian counter-parts to ban pop-rock-metal music where they have power (Roy and Boubekeur 2012). 


\section{Taking drugs and drinking alcohol}

Psychoactive substances such as cannabis and alcohol have been used by humans for thousands of years as a way of altering the mind, bonding and having some pleasurable moments of leisurely respite (Arnold 1999; Goodman, Lovejoy and Sherratt 2007; Spracklen 2011). These substances have been - and continue to be - problematic for religious leaders and secular lawmakers. If the pre-modern use of such substances suggests some ritualistic function, in historical times the legal and moral status of using these substances has been

carefully constrained, if the substances have not been banned altogether (Goodman, Lovejoy and Sherratt 2007). So in the Christian West alcohol has been privileged as a legal psychoactive substance, part of the popular culture of the West, but a drink that has been banned on numerous occasions by Christians concerned about the morality of drinking and the harm that goes with hard-drinking (Yeomans 2014). In contrast, in most Islamic countries and in Islamic theology, alcohol is strictly forbidden (see discussion in Matthee 2014). In most countries that follow the guidelines of the World Health Organisation, recreational drugs such as heroin, cocaine and LSD are banned because they are perceived to be addictive, threatening to life, and threatening to social order. Excessive drinking is also discouraged, and there are warnings about the effects of cannabis that make it remain illegal in many countries (Goodman, Lovejoy and Sherratt 2007). Of course, the banning of recreational drugs such as heroin and cocaine may come as a surprise to anyone who was born in the age of high modernity in the middle of the nineteenth-century, when these modern drugs were sold legally as health-restorers. In the rest of this section I will use 'drugs' to refer to those recreational psychoactive substances that have faced complete prohibition in the West (for example: heroin, speed, cocaine, cannabis, LSD, MDMA or ecstasy), distinguishing them from alcohol, which remains legal if held in suspicion. 
Drugs are widely used in the pop-rock-metal scene, in different places and for different purposes. The industry of pop-rock-metal music is fuelled by stimulants such as speed and cocaine used by producers, musicians, journalists and industry insiders to work and socialise (Bogazianos 2012; Frith 1998; Hoskyns 2006). Others, such as those involved in the hippie scene of the 1960s and 1970s used LSD, or cannabis (Davis 2015). The latter has become widely used throughout music by musicians and fans as a drug to calm nerves and find focus (Wright and DeKemper 2016). Some musicians and members of certain subcultural scenes have become addicted to 'hard' drugs such as heroin, but such addiction and its associated health problems is disproportionately small to the moral scare about drugs in pop-rock-music. Most people are perfectly capable of using drugs to enhance their leisure and pleasure: there is nothing abnormal or deviant in the way most people appear to use drugs in the pop-rock-metal music scene. Dancers take drugs such as MDMA to enhance the pleasure of their nights out (Sanders 2016). Drugs help listeners make sense of music, and the leisure spaces in which music is being listened to, such as the bedroom at night, or the field of a festival.

Drug-use, then, is far less deleterious than the 'Horns Up! Drink Beer!' norms of alcohol drinking in pop-rock-metal music. Despite the existence of straight-edge (abstinent) hardcore and Christian-metal subcultures on the fringes of heavy metal, the subcultures of metal in most of the West remain spaces where excessive alcohol drinking is celebrated. In the film Spinal Tap, the band, their groupies and their fans are hardly ever seen without a bottle of something alcoholic. Alcohol, and beer, is now an essential and legitimate part of the heavy-metal sub-culture:

Have you ever wondered what a Heavy Music show would be without a good amount of cold refreshing beer? It would be like eating a burger without bacon and cheese! 
While we as Metaleros tend to disagree and argue about different bands, we all agree that beer is the international drink of choice for the headbangers of the world. (http://hornsuprocks.blogspot.co.uk/2013/04/today-is-national-beer-day-celebrateit.html, accessed 8 November 2016)

Historically, this normalisation of excessive alcohol drinking has come from the perceived and actual habits of bands, replicated in the masculine performativity of fans at gigs, festival and bars. From Led Zeppelin's John Bonham and his prodigious drinking prowess, to Metallica, nick-named Alcoholica, drinking alcohol is a mark of metalness, and of hegemonic masculinity. It is not enough just to drink alcohol. To be a man like the 1980 s version of James Hetfield, one needed to be able to drink so much that any normal person would die while still being capable of standing up. Only having one beer, or to not drink alcohol at all, or to have moral objections to alcohol - in metal circles, that was, and almost certainly still is in many minds, the mark of a weak, effeminate man (Walser 1993; Spracklen 2015b). Drinking alcohol is something that brings the musicians and the fans together. In the modern metal scene, bands such as Germany's Tankard and Finland's Korpiklaani have made a career singing songs about drinking alcohol. Alcohol drinking is a central part of metal's identity and ideology - to be a metalhead one drinks to excess, following the role models in the scene, and proving to one's peers one is metal enough to be able to take one's drink. Any alcohol will do, but beer is best because of its tactility. With beer one can raise one's bottle or glass as if it is a drinking horn, and be your own Viking for a few seconds.

\section{Satanism}


There is a long history of selling one's soul for rock and roll - or of pretending to do so, or of pretending someone else has done so. For the blues singer and guitarist Robert Johnson, the Devil was someone who appeared as a terrible influence and power in his life:

Early this mornin' when you knocked upon my door

Early this mornin', ooh

When you knocked upon my door

And I said, "Hello, Satan,

I believe it's time to go."

(http://xroads.virginia.edu/ MUSIC/blues/matdb.html, accessed 8 November 2016)

Johnson's early and murderous death has been explained away as the Devil coming to take the soul he was promised when he supposedly gave Johnson the ability to play his guitar in the dead of night, by some ill-fated crossroads (Cowley 1981; Graves 2008; Guralnick 1982; Schroeder 2004; Wells 1983). This is a pernicious and long-standing myth that has grown with the re-telling (Guralnick 1982; Schroeder 2004): Robert Johnson became an important anti-hero for the rock musicians of the 1960s and 1970s (Graves 2008). Rumours about Faustian pacts with Satan surrounded Led Zeppelin and especially their guitarist Jimmy Page, who was clearly interested in the story of Johnson, as well as the 'occult magick' of Aleister Crowley (Hutchinson 2011). The Rolling Stones and Black Sabbath deliberately played with the idea of Satanism, but this play was just that: effect and performativity. For the Rolling Stones, their commitment to Satanism was transient and tied-up with their wish to shock middle England (Young 2011). For Black Sabbath, Satan was just a pantomime baddy brought on to sell records (Cope 2016). 
Most pop-rock-metal music scenes and genres are not inspired by Satanism, other than the harmless 'devil-horn' salute that has become ubiquitous in modern pop; and even the devil-horns are originally a way to ward off the Devil, the evil eye or evil magic popularised on-stage by Ronnie James Dio (Rossolatos 2014). Pop-rock-metal music is many things, but the root of all evil it is certainly is not, even if religious reactionaries and conspiracy nuts (and their readers on-line and in the local church or mosque) think it is. Madonna, for example, has been held up as a secret follower of the Illuminati, spreading the evil of Satan, through her appearance and performance at the 2015 Grammy Awards (http://www.al.com/news/index.ssf/2015/02/2015_grammys_illuminati_rumors.html, accessed 8 November 2016). Such loose reasoning is absurd. Madonna is selling her image and her music, and is a key star in the music industry, but that is not a conspiracy to loosen morals, or a result of some pact. Pop-rock-metal music is just a part of the secular, profane popular culture of modernity.

But there are a few scenes which lay claim to Satanism, dark magic, heathenism: among the extreme edges of the goths influenced by esoteric, pagan and Satanist ideologies (Spracklen and Spracklen, 2012); and of course, in the heathenism, elitism and outright Satanism of black metal (Granholm 2011; Reyes 2013; Spracklen, 2006). The feeling when listening to self-described Orthodox Satanic black metal bands such as Gorgoroth or Watain, or watching a performance of those bands, is that the homage to Satan is real. This is a ritual, a way of expressing a belief in some occult intelligence or force, even if that force is internal to or made real in the performer (Granholm 2011; Partridge 2014). But how much of this is real Satanism, and how much is a combination of performance and show-business? Satanic black-metal musicians cannot easily break the trust of their audiences by showing they are not the real deal. 


\section{Discussion}

Pop-rock-metal music owes its dark elements to what came before it - blues, jazz, and other forms of what we might call early popular music produced in the early twentieth century (Cowley 1981; Frith 1998; Wells 1983). This popular music was music to drink to, music to dance to, and music to help people find romance and sexual partners. The musicians who constructed blues and jazz drank and got high, got involved in their own sexual encounters, and wrote songs that reflected that bad behaviour through the shimmer of suggestive metaphors. The black ethnicity of many of these musicians in America became another way for sex and drugs to be marked as objectionable, wild leisure practices of liminal sub-alterns. So-called 'negro' music became constructed as a mimetic leisure space, in which black people behaved appallingly, and the concerned white middle-classes became fearful that their sons and daughters would be contaminated by it (Schroder 2004). Although the phrase 'sex and drugs and rock and roll' was coined in the 1970s, the connection between the three (where rock and roll is read as popular music) was made in the minds of the Moral Majority in the United States in the 1930s onwards.

Pop-rock-metal music, then, also owes its dark elements to what is morally objectionable in societies shaped by religious imperatives and commandments. Sex and drugs are forbidden and controlled by religious morality, especially the fundamentalist Christian form that shaped the norms and values of the space in which rock and roll emerged (Frith 1998) - so they have become part of the norm of pop music's counter-hegemonic resistance.

Sex and drugs are part of rock and roll because they are dark leisure practices that denote mephitic leisure; they may be marked as wild by those agents performing them, and by the moral crusaders fighting them. But they are mimetic or performative in nature. They are also part of the commercial, commodification of leisure by the cultural industries (Adorno 1991). Satanism feels truly deviant, invasive and communicative, but seems to be mainly 
mimetic. The rules and instrumental rationality of black metal, which is the rationality of metal and rock more generally, have to be followed to make careers: resist the mainstream, burn a church, but buy my tee-shirts and records please.

\section{Conclusion}

Dark leisure as deviant leisure is too simplistic, and based on religious morality. Dark leisure is only dark through a political and moral elite's imposition of what is legitimate, and what is liminal. Dark leisure is only dark because, as Williams (2008) indicates, the deviance has become medicalized: individuals are accounted to be deviants because of a failing in their soul, or a failing in their body, and either way their leisure is controlled. How this occurs in other leisure spaces is an urgent future research issue. Dark leisure as Rojek's three-fold abnormal leisure is useful in defining the ways in which humans as agents work in and through dark leisure to perform identity. But whether invasive, mephitic, or wild, such abnormal leisure fails to adequately situate the agent in the wider structures of late modernity and global capitalism. Dark leisure as abnormal leisure cannot account for the invention of dark leisure by cultural industries, and the use of dark leisure to constrain. Dark leisure, then needs to be framed by Habermasian rationalities to situate it in the public and private spheres of the contemporary world. That is, dark leisure needs to be understood as being a space or activity shaped by a communicative rationality to transgress and rebel, and by the instrumentality that constrains it: the conservative, morality of the major religions of the West. 


\section{References}

Adorno, T. 1991 The Culture Industry. London: Routledge.

Arnold, B. 1999. "Drinking the Feast: Alcohol and the Legitimation of Power in Celtic Europe." Cambridge Archaeological Journal 9 (1): 71-93.

Ashley, M. 2011. "The Perpetuation of Hegemonic Male Power and the Loss of Boyhood Innocence: Case Studies from the Music Industry." Journal of Youth Studies 14 (1): 59-76.

Bakhtin, M. 1984. Rabelais and His World. Chichester: John Wiley and Sons.

Bataille, G. 1985. Visions of Excess: Selected Writings, 1927-1939. Minneapolis: University of Minnesota Press.

Becker, H. S. 2008. Outsiders. London: Simon and Schuster.

Birch, W. 2010. Ian Dury: The Definitive Biography. London: Pan Macmillan.

Blackshaw, T., and T. Crabbe. 2004. New Perspectives on Sport and 'Deviance':

Consumption, Performativity and Social Control. New York: Psychology Press.

Bogazianos, D. A. 2012. 5 Grams: Crack Cocaine, Rap Music, and the War on Drugs. New York: NYU Press.

Brill, D. 2008. Goth Culture: Gender, Sexuality and Style. Oxford: Berg.

Butler, J. 2006 Gender Trouble: Feminism and the Subversion of Identity. Abingdon: Routledge.

Cloonan, M. 1995. "Popular Music and Censorship in Britain: An Overview." Popular Music and Society 19 (3):75-104.

Cohen, A. K. 1965. "The Sociology of the Deviant Act: Anomie Theory and Beyond." American Sociological Review 30 (1): 5-14.

Cohen, S. 2002. Folk Devils and Moral Panics: The Creation of the Mods and Rockers. New York: Psychology Press.

Cope, A. L. 2016. Black Sabbath and the Rise of Heavy Metal Music. New York: Routledge. 
Cowley, J. 1981. “Really the 'Walking Blues': Son House, Muddy Waters, Robert Johnson and the Development of a Traditional Blues." Popular Music 1: 57-72.

Curtis, J. E. 1988. "Purple Recreation.” Society of Park and Recreation Education National Recreation and Park Association Annual on Education 3:73-77.

Darling-Wolf, F. 2004. "SMAP, Sex, and Masculinity: Constructing the Perfect Female Fantasy in Japanese Popular Music.” Popular Music and Society 27 (3): 357-370.

Davis, J. C. 2015. “The Business of Getting High: Head Shops, Countercultural Capitalism, and the Marijuana Legalization Movement." The Sixties 8 (1): 27-49.

Debord, G. 1977. Society of the Spectacle. Michigan: Black and Red.

Deleuze, G. 2014. Difference and Repetition. London: Bloomsbury.

Deleuze, G. 2015. Logic of Sense. London: Bloomsbury.

Dhoest, A., Malliet, S., Haer, J., and B. Segaert. 2015. The Borders of Subculture: Resistance and the Mainstream. New York: Routledge.

Drozda, C. 2006. "Juveniles Performing Auto Theft: An Exploratory Study into a Deviant Leisure Lifestyle.” Leisure/Loisir 30 (1): 111-132.

Dury, J. 2003. Ian Dury and the Blockheads: Song by Song. London: Sanctuary.

Fast, S. 1999. "Rethinking Issues of Gender and Sexuality in Led Zeppelin: A Woman's View of Pleasure and Power in Hard Rock.” American Music 17 (3): 245-299.

Foucault, M. 1991. Discipline and Punish: The Birth of the Prison. Harmondsworth: Penguin.

Foucault, M. 2002. The Archaeology of Knowledge. Abingdon: Routledge.

Foucault, M. 2005. Madness and Civilisation. Abingdon: Routledge.

Franklin-Reible, H. 2006. 'Deviant Leisure: Uncovering the 'Goods' in Transgressive Behaviour.” Leisure/Loisir 30 (1): 55-71. 
Frith, S. 1998. Performing Rites: On the Value of Popular Music. Cambridge: Harvard University Press.

Galloway, S. 2006. “Adventure Recreation Reconceived: Positive Forms of Deviant Leisure.” Leisure/Loisir 30 (1): 219-231.

Goodman, J., Lovejoy, P. E., and A. Sherratt. 2007. Consuming Habits: Global and Historical Perspectives on how Cultures Define Drugs. New York: Psychology Press. Granholm, K. 2011. "Sons of Northern Darkness: Heathen Influences in Black Metal and Neofolk Music.” Numen 58 (4): 514-544.

Graves, T. 2008. Crossroads: The Life and Afterlife of Blues Legend Robert Johnson. Spokane: Demers Books.

Gunn, L., and L. T. Caissie. 2006. "Serial Murder as an Act of Deviant Leisure." Leisure/Loisir 30 (1): 27-53.

Guralnick, P. 1982. Searching for Robert Johnson. Harmondsworth: Penguin.

Habermas, J. 1984. The Theory of Communicative Action, Volume One: Reason and the Rationalization of Society. Cambridge: Polity.

Habermas, J. 1987. The Theory of Communicative Action, Volume Two: The Critique of Functionalist Reason. Cambridge: Polity.

Hebdige, D. 1979. Subcultures: The Meaning of Style. London: Routledge.

Holland, S. 2004. Alternative Femininities: Body, Age and Identity. Oxford: Berg.

Hoskyns, B. 2006. Hotel California: Singer-songwriters and Cocaine Cowboys in the LA Canyons 1967-1976. London: HarperCollins.

Howard, J. R., and J. M. Streck. 1996. “The Splintered Art World of Contemporary Christian Music.” Popular Music 15 (1): 37-53. 
Hurley, J. M. 1994. "Debate: Music Video and the Construction of Gendered Subjectivity (or how being a Music Video Junkie Turned me into a Feminist).” Popular Music 13 (3): 327338.

Hutchinson, R. 2011. Aleister Crowley: The Beast Demystified. London: Random House. Jayne, M., Valentine, G., and S. L. Holloway. 2008. "Geographies of Alcohol, Drinking and Drunkenness: A Review of Progress.” Progress in Human Geography, 32 (2): 247-263. Kahn-Harris, K. 2007. Extreme Metal. Oxford: Berg.

Lindsey, L. L. 2015. Gender Roles: A Sociological Perspective. Abingdon: Routledge.

Matheson, C. M., and R. Tinsley. 2016. “The Carnivalesque and Event Evolution: A Study of the Beltane Fire Festival.” Leisure Studies 35 (1):1-27.

Matthee, R. 2014. "Alcohol in the Islamic Middle East: Ambivalence and Ambiguity." Past and Present 222 (9): 100-125.

McKay, G. 2009. “Crippled with Nerves: Popular Music and Polio, with Particular Reference to Ian Dury." Popular Music 28 (3): 341-365.

Milton-Edwards, B. 2013. Islamic Fundamentalism since 1945. Abingdon: Routledge.

Misiroglu, G. 2015. American Countercultures: An Encyclopedia of Nonconformists, Alternative Lifestyles, and Radical Ideas in US History. New York: Routledge.

Oppermann, M. 1999. “Sex Tourism.” Annals of Tourism Research 26 (2): 251-266.

Patton, M. S. 1985. “Masturbation from Judaism to Victorianism.” Journal of Religion and Health 24 (2): 133-146.

Railton, D. 2001. “The Gendered Carnival of Pop.” Popular Music 20 (3): 321-331.

Reyes, I. 2013. "Blacker than Death: Recollecting the "Black Turn" in Metal Aesthetics." Journal of Popular Music Studies 25 (2): 240-257.

Rojek, C. 1995. Decentring Leisure. London: Sage. 
Rojek, C. 1999. “Abnormal Leisure: Invasive, Mephitic and Wild Forms.” Loisir et Société/Society and Leisure 22 (1): 21-37.

Rojek, C. 2000. Leisure and Culture. London: Sage.

Rojek, C. 2010. The Labour of Leisure. London: Sage.

Rossolatos, G. 2014. “A Dio: A Sociosemiotic/Phenomenological Account of the Formation of Collective Narrative Identity in the Context of a Rock Legend's Memorial.” Southern Semiotic Review 5(1): 81-105.

Roy, O., and A. Boubekeur. 2012. Whatever Happened to the Islamists? Salafis, Heavy Metal Muslims and the Lure of Consumerist Islam. New York: Columbia University Press.

Runkel, G. 1998. "Sexual Morality of Christianity.” Journal of Sex and Marital Therapy 24 (2): 103-122.

Sanders, B. 2016. Drugs, Clubs and Young People: Sociological and Public Health Perspectives. Abingdon: Routledge.

Schroeder, P. R. 2004. Robert Johnson, Mythmaking, and Contemporary American Culture. Champaign: University of Illinois Press.

Simoni, V. 2014. "Coping with Ambiguous Relationships: Sex, Tourism, and Transformation in Cuba. Journal of Tourism and Cultural Change 12 (2): 166-183.

Spracklen, K. 2006. "Leisure, Consumption and a Blaze in the Northern Sky: Developing an Understanding of Leisure at the End of Modernity through the Habermasian Framework of Communicative and Instrumental Rationality.” World Leisure Journal 48 (3): 33-44.

Spracklen, K. 2009. The Meaning and Purpose of Leisure: Habermas and Leisure at the End of Modernity. Basingstoke: Palgrave Macmillan.

Spracklen, K. 2011. Constructing Leisure: Historical and Philosophical Debates. Basingstoke: Palgrave Macmillan.

Spracklen, K. 2013. Whiteness and Leisure. Basingstoke: Palgrave Macmillan. 
Spracklen, K. 2014. “There is (Almost) no Alternative: The Slow 'Heat Death' of Music Subcultures and the Instrumentalization of Contemporary Leisure." Annals of Leisure Research 17 (3): 252-266.

Spracklen, K. 2015a. Digital Leisure, the Internet and Popular Culture: Communities and Identities in a Digital Age. London: Palgrave Macmillan.

Spracklen, K. 2015b. "To Holmgard... and Beyond: Folk Metal Fantasies and Hegemonic White Masculinities.” Metal Music Studies 1(3): 354-377.

Spracklen, K., and I. Lamond. 2016. Critical Event Studies. Abingdon: Routledge.

Spracklen, K., and B. Spracklen. 2012. "Pagans and Satan and Goths, Oh My: Dark Leisure as Communicative Agency and Communal Identity on the Fringes of the Modern Goth Scene.” World Leisure Journal 54 (4): 350-362.

Spracklen, K., and B. Spracklen. 2014. "The Strange and Spooky Battle over Bats and Black Dresses: The Commodification of Whitby Goth Weekend and the Loss of a Subculture.” Tourist Studies 14 (1): 86-102.

Stebbins, R. A. 1982. "Serious Leisure: A Conceptual Statement.” Sociological Perspectives 25 (2): 251-272.

Stebbins, R. A. 1996. Tolerable Differences: Living with Deviance. Toronto: McGraw-Hill. Stebbins, R. A. 1997. “Casual Leisure: A Conceptual Statement.” Leisure Studies 16 (1): 1725.

Stebbins, R. A. 2001. "The Costs and Benefits of Hedonism: Some Consequences of Taking Casual Leisure Seriously.” Leisure Studies 20 (4): 305-309.

Stebbins, R. A. 2005. "Project-based Leisure: Theoretical Neglect of a Common Use of Free Time.” Leisure Studies 24 (1): 1-11.

Stone, P. R., and R. Sharpley. 2013. “Deviance, Dark Tourism and 'Dark Leisure': Towards a (Re)configuration of Morality and the Taboo in Secular Society." In Contemporary 
Perspectives in Leisure: Meanings, Motives and Lifelong Learning, edited by Sam

Elkington and Sean Gammon, 59-64. Abingdon: Routledge.

Swedenburg, T. 1997. "Saida Sultan/Danna International: Transgender Pop and the Polysemiotics of Sex, Nation, and Ethnicity on the Israeli-Egyptian border.” The Musical Quarterly 81 (1): 81-108.

Tucker, F., and H. Matthews. 2001. “They Don’t Like Girls Hanging around There: Conflicts over Recreational Space in Rural Northamptonshire.” Area 33 (2): 161-168.

Urry, J. 2012. Sociology Beyond Societies: Mobilities for the Twenty-first Century. Abingdon: Routledge.

Walser, R. 1993. Running with the Devil: Power, Gender, and Madness in Heavy Metal Music. Hanover: Wesleyan University Press.

Warkentin, E. 2010. “Jack the Ripper Strikes Again: The 'Ipswich Ripper' and the 'Vice Girls’ He Killed.” Feminist Media Studies 10 (1): 35-49.

Wells, J. D. 1983. "Me and the Devil Blues: A Study of Robert Johnson and the Music of the Rolling Stones." Popular Music and Society 9 (3): 17-24.

Williams, D. J. 2008. “Contemporary Vampires and (Blood-red) Leisure: Should We be Afraid of the Dark?" Leisure/Loisir 32 (2): 513-539.

Williams, D. J. 2009. "Deviant Leisure: Rethinking 'the Good, the Bad, and the Ugly'." Leisure Sciences 31 (2): 207-213.

Williams, D. J., and G. J. Walker. 2006. 'Leisure, Deviant Leisure, and Crime: 'Caution: Objects May Be Closer Than They Appear'”. Leisure/Loisir 30 (1):193-218.

Winge, T. M. 2012. Body Style. London: Bloomsbury.

Wright, C. L., and D. DeKemper. 2016. "Music as a Mediator between Ethnicity and Substance Use among College Students.” Journal of Ethnicity in Substance Abuse 15 (2): 189-209. 
Wright, R. 2000. "I'd sell you Suicide: Pop Music and Moral Panic in the Age of Marilyn

Manson.” Popular Music 19 (3): pp.365-385.

Yeomans, H. 2014. Alcohol and Moral Regulation: Public Attitudes, Spirited Measures and Victorian Hangovers. Bristol: Policy Press.

Young, J. 2011. "Moral Panics and the Transgressive Other." Crime, Media, Culture 7 (3): $245-258$.

Yuen Thompson, B. 2015. Covered in Ink: Tattoos, Women and the Politics of the Body. New York: NYU Press.

\footnotetext{
1 By this, I mean all forms of music known as Electronic Dance Music (EDM).

2 For a leisure studies perspective, and for a useful introduction, see Blackshaw and Crabbe (2004).

3 Knowing of course that many people in these groups do not choose to be in them, but are coerced, bullied or co-opted into them (Blackshaw and Crabbe 2004).

4 For an example of a historical and philosophical exegesis of transgression see the discussion in the chapter on events, misrule and liminality in Spracklen and Lamond (2016).

5 For theories of the meaning of leisure and discussions of the definition of leisure see Rojek $(2000,2010)$ or Spracklen (2006, 2009, 2011).
} 